\title{
Identifying social-ecological couplings for regional sustainability in a rapidly urbanizing water-limited area of western Canada
}

\author{
M. E. Tyler ${ }^{1} \&$ M. S. Quinn ${ }^{2}$ \\ ${ }^{1}$ Faculty of Environmental Design, University of Calgary, Canada \\ ${ }^{2}$ Institute for Environmental Sustainability, \\ Mount Royal University, Canada
}

\begin{abstract}
Regional planning for sustainability is predicated on an ability to create and maintain resilient social-ecological systems that are adaptable in the face of surprise and change. One of the central challenges is to understand, articulate and manage the connections between social systems and the physical environment. Over the last fifty years economic 'booms' associated with abundant oil and gas resources have driven rapid regional population growth and large scale landscape change in the Calgary region. However, the region is a semi-arid and temperate area where growth-related land use planning is quite literally water dependent. Climate change modeling suggests even warmer and drier conditions in the region making the critical relationship between land-use and water increasingly acute. A voluntary regional partnership of local municipal governments has emerged over the past six years to address common land use planning concerns emerging from the rapid anthropogenic and natural changes affecting the region. In this paper we explore some of the critical socialecological couplings that have emerged as drivers for sustainability and resilience in the Calgary region of southwestern Alberta, Canada. We posit critical social-ecological and spatial couplings involving: 1) the intersection of built infrastructure (transportation, irrigation and utility corridors) and ecological infrastructure (landscape connectivity), and 2) regional ecohydrology and human water use.
\end{abstract}

Keywords: social-ecological systems (SES), coupled human and natural systems (CHANS), resilience, regional planning, sustainability, ecohydrology. 


\section{Introduction}

Social-ecological systems (SES) are a 'synthesis' of human and ecological processes, interactions and interconnections. They are 'emergent' systems insofar as they are not simply a social system + an ecological system and, as such, cannot be modelled as analogous to either an ecosystem or a socioeconomic system.

Liu et al. [1] define coupled human and natural systems (CHANS) as "integrated systems in which people interact with natural components." CHANS are characterized by nonlinear human and ecological process interactions and complex reciprocal feedback loops that are socioecological as well as socioeconomic. In a CHANS framework, integrated human-ecological process interactions function as co-regulators of SES functional dynamics in time and space. Human activities do not just exist 'outside' of ecological systems and have impacts upon them; they are an integral part of ecological system function and are becoming increasingly dominant. A co-regulators approach differs significantly from a conventional impact model such as the EEA [2] DriversPressure-State-Impact-Response effect chain. In a CHANS framework, system dynamics and threshold effects are characterized by nonlinearity. SES drivers and responses represent reciprocal anthropogenic and ecological (abiotic-biotic) processes. Human and natural systems co-evolve and co-regulate change, instability and mutual adaptation across scales.

To date, much of the research into CHANS and SES has focussed on rural and indigenous social-ecological systems (Berkes and Folke [3], Berkes et al. [4]). However, Lui et al. [1] suggest, urban social-ecological systems and couplings are substantively different insofar as they "are mediated by factors such as the urban form, built infrastructure, and location and consumption patterns of heterogeneous households and businesses." Social innovation, technological innovation, economic opportunity and changes in sociocultural organization and preferences have resulted in rapid urbanization and growing city regions together with massive rural to urban land use transitions (Lambin and Meyfroidt [5]). While such human drivers of environmental change may initially appear to be exogenous to ecological systems, their reconciliation over time will depend upon co-regulation by endogenous social-ecological couplings.

Crutzen and Stoermer [6] proffered the term 'Anthropocene' to describe a new geologic period in which humankind is the dominant force in the biogeoclimatic transformation of our planet. While there has been some controversy regarding this term, the dominant influences and functions of human activities on the function and evolution of the Earth system is becoming increasingly recognized (Steffen et al. [7], Vitousek et al. [8], Zalasiewicz et al. [9]). For example, in 2012, a new international scientific journal named 'Anthropocence' was founded to address the nature, scale, and extent of the influence that people have on Earth (Elsevier [10]). Similarly, Zalasiewicz et al. [9] are unequivocal in stating that addressing the Anthropocene "is now arguably the most important question of our age - scientifically, socially and politically. We cannot think of a greater or more urgent challenge.” 
Scheffer et al. [11] state it is becoming increasingly clear that many complex systems, including CHANS, have "critical thresholds - so-called tipping points at which the system shifts abruptly from one state to another." Such abrupt state shifts or critical transitions are potentially catastrophic. Therefore much of the international research focus on resilience theory is to identify possible warning signs of such transitions. The potential large scale negative socioeconomic consequences of critical transformations is part of the current rationale for incorporating resilience theory and resilience thinking into adaptive ecosystem management and sustainable urban and regional systems governance (Stockholm Resilience Centre [12]).

The growing acknowledgement of increasingly tight couplings between human and natural sub-systems within the overall planetary system is fostering research to understand and ultimately manage resilience and sustainability (Jahn et al. [13]). The research we describe in this paper is in the context of a rapidly growing semi-arid region and is intended to identify clues for identifying critical regional SES couplings and manage them at a regional landscape scale.

\subsection{Social-ecological couplings across scales}

The 'regional analysis of social-ecological systems' (RASE) is one approach to understanding CHANS that has emerged in the context of environmental monitoring for environmental management (Bourgeron et al. [14]). The general steps in a RASE approach are illustrated in Fig. 1. According to Bourgeron et al. [14], there are three fundamental stages involved in RASE development; and five region-specific knowledge requirements. These can be produced through the analysis and interpretation of available data and maps of historical and current biological conditions and human activities and include:

- Identification of key inter-relationships among ecosystem components and integration of socioeconomic, land use and biological data.

- Identification of scaled relationships between RASE data acquisition and strategic scenarios.

- Identification of spatial scales for six types of boundaries used in RASE (including: assessment area, characterization area, analysis area, cumulative impact area, reporting unit).

- Description of SES as a whole, including coupling of components and system properties such as disturbances and resilience.

The substantive nature of these information requirements requires detailed and specialized information not always readily available. There is also a high degree of subjective interpretation and expert opinion required for identification of important or critical social-ecological couplings and their thresholds. However, as hypothetical as a RASE approach may be, it has regional to local cross-scalar application (as illustrated in Fig. 2).

Walker et al. [15] state: “A regional SES does not consist of just one kind of cycle at one scale. It functions as a nested, hierarchical structure, with processes 


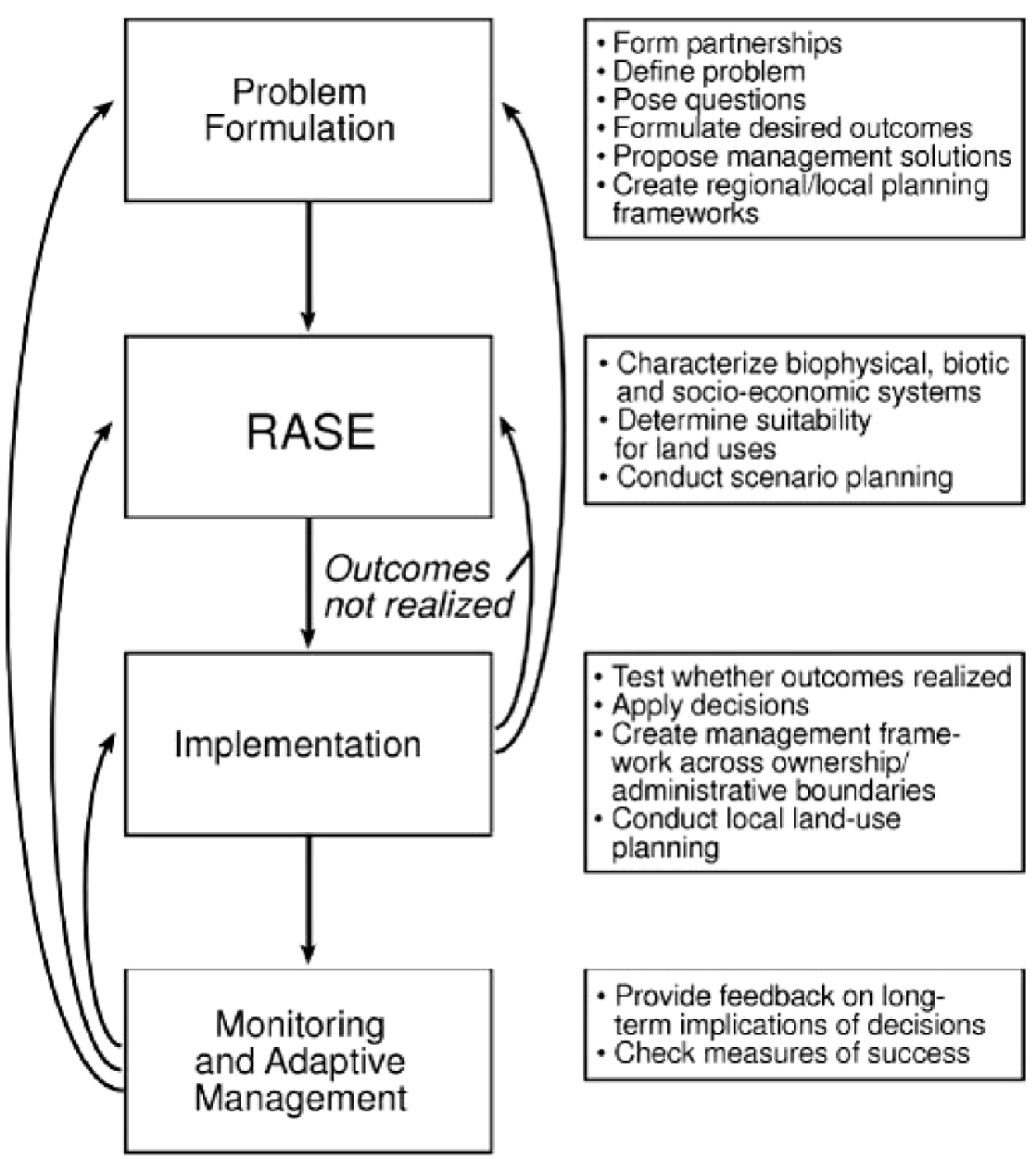

Figure 1: $\quad$ RASE approach (Bourgeron et al. [14]).

clustered within subsystems at several scales." Likewise, Gunderson and Holling [16] stress the importance of multi-scale approaches. Therefore, the identification of social-ecological couplings needs to recognize and reflect these various scales and rates in terms of fast and slow variables and stages in adaptive cycles.

Cross-scalar processes are also important because of the significance of, and potential for, cascading effects. As described by Peters et al. [17]: "Cascading events that start at small spatial scales and propagate non-linearly through time to influence larger areas often have major impacts on ecosystem goods and services.” Cascading events are often driven by linked ecological and human processes across scales which illustrate the critical linkages between land use decisions and ecosystem dynamics. They also demonstrate "non-linear 


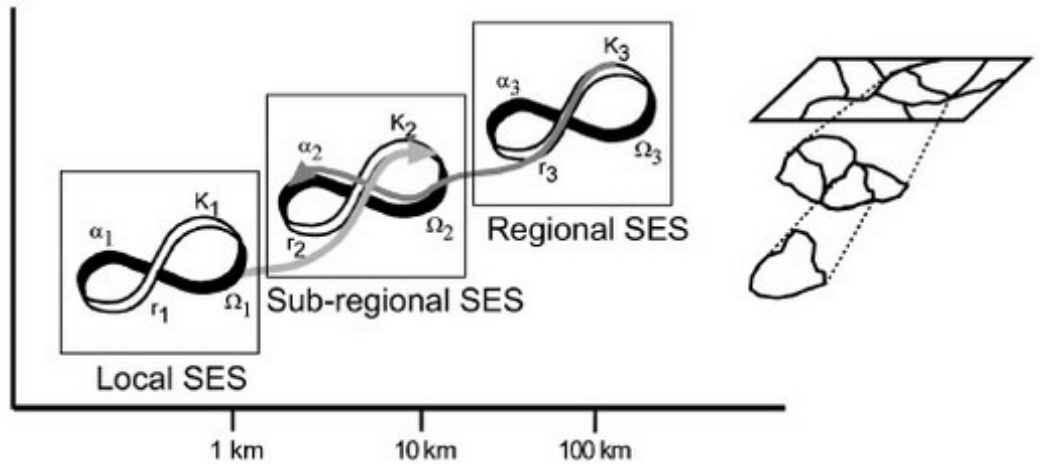

Figure 2: $\quad$ Cross-scalar application of RASE approach (Bourgeron et al. [14]).

aggregation of fine-scale processes with unanticipated effects at broader scales” [17]. Therefore, it becomes increasingly critical to identify and understand such cascading effects within CHANS.

Attempts to identify critical social-ecological couplings have illustrated that there is a disconnection between human decision-making and complex system variability. This disconnection is addressed by Milly et al.'s [18] declaration that "stationarity is dead." This refers to the traditional practice in water resource engineering of assuming stationarity ("the idea that natural systems fluctuate within an unchanging envelope of variability") in water resource planning and management. Unfortunately, there is evidence of increasing uncertainty rather than predictability which has rendered stationarity 'dead' because "substantial anthropogenic change of Earth's climate is altering the means and extremes of precipitation, evapotranspiration and rates of discharge of rivers” [18]. Therefore, new approaches are necessary for engaging uncertainty and nonlinearity in order to assist human adaptation to unpredictable climate system dynamics. Holling and Meffe [19] have previously described this disconnection problem in terms of the pathology of command and control approaches to natural resource management. These approaches to system modelling are disconnected from the nonlinear and uncertain behaviour of the complex adaptive systems being managed which has resulted in surprise.

One proposition for the study of SES is that the social and ecological domains can both be handled in a common framework (Walker et al. [20]). In the case studies presented by Lui et al. [1], these couplings exhibited variance and nonlinear system dynamics which suggests that the couplings themselves may provide much of the critical information needed to understand social-ecological systems. Therefore, an initial heuristic approach to identify propositions for social-ecological couplings was suggested by Walker et al. [20] as a starting point for dealing with system complexity uncertainty. In this paper, we posit two initial heuristic relationships and regionally significant 'clues' for the Calgary metropolitan region in western Canada. 


\section{A role for network analysis}

Network approaches to social-ecological systems have the potential to provide a common language that could be used to integrate the study of social and ecological systems (Janssen et al. [21]). Network analysis techniques have been used in resilience and robustness assessment as a proxy for resilience in socialecological systems (Janssen et al. [21], Anderies et al. [22]). A network construct can represent the components of any system and the relationships between them. Components are represented as nodes and the relationships are represented as links or edges and its composition depends on the attributes of the system and the purpose of the analysis. In an SES context, nodes can represent either social or ecological components or a mix of the two (Janssen et al. [21]). It is this ability to mix social and ecological links that shows promise for network SES analysis. However, integration is one of the greatest challenges in network analysis and as yet there is no clear consensus on a single method (Cumming et al. [23]).

A network can be used to model the flow of water through a system (Bodini [24]). A purely ecological implementation would include only water bodies in the network. A social network can also be built to represent human modifications of vegetation cover, flow control measures, water withdrawals, and influence on other human actors (Stein et al. [25]). By including human flow diversions (wells, agriculture, etc.) the network can represent interactions between water-related social and ecological components. Resilience in SES does not refer to specific aspects or measurements of system characteristics. Rather, it represents a framework for thinking about system dynamics in order to gain insights into how they behave (Anderies et al. [26]). However, specific ways of analysing social-ecological system dynamics using networks have emerged. Connectivity and centrality metrics are applicable to any type of network. These methods are well documented in the network analysis literature (e.g., Bodin et al. [27], Janssen et al. [21]). We have selected connectivity metrics, specifically permeability and centrality, for SES application in the Calgary region.

\section{Critical social-ecological couplings in the Calgary region}

The work represented here is part of a larger transdisciplinary research program we are involved in with the Calgary Regional Partnership. The partnership is a voluntary consortium of municipalities with the goal of regional sustainability. Our approach is to employ a social-ecological systems (SES) approach to cocreate an ecological governance framework for integrating land use planning and water management into strategic regional planning. This is demonstration research aimed at advancing both theory and practice in sustainable regional planning. AtKisson [28] suggests: "Sustainable development always begins, formally or informally, in a confrontation with information.” The critical socialecological couplings described below are an attempt to confront the information available at a regional or landscape scale. Subsequent analyses will be required to further explore the connections at sub-regional and local scales. The overall 
intent is to identify critical areas of focus in a sea of potentially useful information. In the following sections of the paper, we focus on critical socialecological couplings in the context of regional ecohydrology and landscape connectivity.

\subsection{Water: social-ecohydrological connections}

The Calgary metropolitan region of western Canada is located in a landscape characterized by an elevation, topographic and hydrologic gradient that extends from the Rocky Mountain Continental Divide east to the mixed-grass plains. The land decreases in elevation (3,400 $\mathrm{m}$ to $800 \mathrm{~m})$, relief (mountainous to flat) and precipitation ( $\sim 950 \mathrm{~mm} / \mathrm{yr}$. to $\sim 350 \mathrm{~mm} / \mathrm{yr}$.) from west to east. The westernmost portions of the region occur in the rugged Rocky Mountains and contain the headwaters for surface and groundwater systems that supply moisture to the prairies. The city of Calgary (population 1.2 million) is situated approximately in the centre of the region (see Fig. 3). The rain shadow effect of the Rocky Mountains results in a semi-arid continental climate as the landscape east of the foothills has an annual evaporation rate that exceeds the rate of annual precipitation. Water availability is the limiting factor for primary productivity in the region and is thus the critical regulating variable for all associated ecological goods and services.

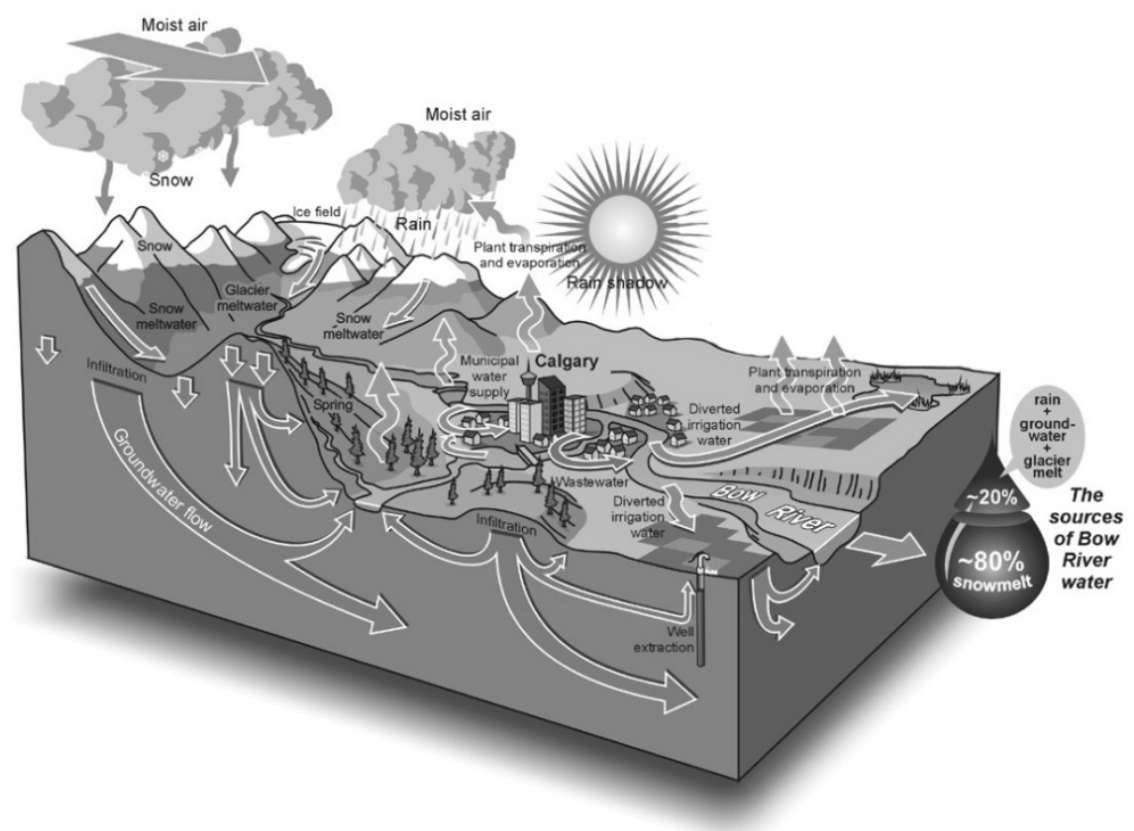

Figure 3: Stylized depiction of the Calgary regional hydrologic system and the elevation, topographic and hydrologic gradients (Turner et al. [29]). 
In a semi-arid region, water is also a primary limiting factor for human development. A recent report on water in the region sums up the situation succinctly: "While Alberta's economy is fuelled by hydrocarbons, it runs on water” (Alberta Water Smart [30]). The hydrological basin in which the Calgary region is located (South Saskatchewan River Basin) is recognized as being fully allocated with respect to water licenses; the provincial regulator has deemed that no new allocations will be granted (Alberta Environment [31]). Two significant trends are expected to exacerbate the current water limitations in the Calgary region: 1) human population growth, and 2) climate change.

The growth rates of communities within the Calgary regional are among the highest in Canada. The current annual growth rate of $1.5 \%$ will result in a doubling of the population in the next 50 years. The increase in population will have concomitant demands on the hydrologic system; not only through direct withdrawals, but through alteration of hydrologic flows via land-use expansion and intensification.

Analysis of tree-ring data for drought severity indicates that the drought conditions experienced in western North America between 2000 and 2004 were the most severe in the past 800 years (Cook and Spray [32]). Climate change modelling suggests that this type of drought "will be commonplace through the end of the twenty-first century. Furthermore, projections suggest that this drought is likely to become the 'wet' end of a drier hydroclimate period in the latter half of the twenty-first century" (Schwalm et al. [33]). Climate change is also expected to have an effect on the timing and nature of regional precipitation. Specifically, mountain snowpack currently accounts for approximately $80 \%$ of the annual flow in the Bow River, a primary water source in the region and the most significant reservoir in the regional hydrologic system. Future projections suggest a decline in mountain snowpack due to a seasonal shift to more precipitation falling as rain. This could have significant detrimental effects on the Bow's current flow regime (Bow River Project Research Consortium [34]). Finally, glacial melt is currently contributing a relatively small amount of the annual flow. However, this contribution arrives during low flow stage late in the summer when human and ecological demand is highest. Therefore, the decline and eventual loss of glacier input during late summer low flows could result in water shortages and lethal low flow conditions for river biota. This could have a major impact on the River's recreational trout fishery and its economic value.

We posit that the social-ecological couplings between regional ecohydrology and anthropogenic water use are critical and need to be better understood. The following are the most salient characteristics of regional hydrologic context:

1) water is the primary limiting factor for the regional social-ecological system, 2) the water supply is already fully (over) committed, 3) the demand for water is likely to increase with expected regional population growth, 4) climate change projections suggest that water supply will decline significantly, and 5) the temporal flow regime may be negatively affected.

The most obvious and direct SES coupling in the regional hydrological cycle is the withdrawal of water for domestic, agricultural and industrial purposes. In 2010, the combined water allocation (maximum licensed removal) from the Bow 
River was 2,801 million $\mathrm{m}^{3}$ (approximately 65\% of the annual flow) (Bow River Basin Council [35]). Irrigation and other agricultural uses accounted for $71 \%$ of the allocation, followed by municipal use (18\%), industrial (2\%), fish and wildlife habitat (7\%) and other (2\%). The allocation values do not represent the net removal of water from the system because: 1) not all of the allocations are used, and 2) some of the water is returned (e.g., sewage treatment from municipalities, storm water return and irrigation return flow [35]). Understanding water withdrawal and diversion from a systems perspective helps to identify the feedbacks to other parts of the social-ecological system. From social, economic and political perspectives, the availability of water for human use (growth) constitutes the most challenging and contentious arena of debate in the region. This is recognized in the Calgary Regional Partnership's most recent Metropolitan Plan, which identifies water and watershed management as the Plan's first principle (Calgary Regional Partnership [36]). Alteration of natural flows and the return of water with thermal and/or chemical pollution also have synergistic and cascading ecological effects. For example, decreased dissolved oxygen, nutrification (phosphorous), sedimentation, increased water temperature and an increase in toxic chemicals and pharmaceuticals (endocrine disrupters) have all been identified in the Bow River and present significant risks to the resilience of the system (Alberta Environment [37], Chen et al. [38]). Feedbacks between social and ecological water subsystems are diverse and complex and represent essential intervention opportunities for planning and management as well as triggers for initiating system change.

A second critical coupling at the regional scale is represented by the link between ecohydrology and land-use (Wilcox et al. [39]). Although planners and managers tend to focus primarily on the allocation of surface water flows (blue flow), approximately $65-70 \%$ of water in the semi-arid environs of the Calgary region is entrained in soil moisture and vegetation (green flow) (Falkenmark and Rockstrom [40]). As a result, land-use is a direct mechanism for managing water. A regional ecohydrological perspective allows for the identification of key leverage points in the system. For example, Fig. 4 illustrates site specific hydrological alterations at the local level. When occurring cumulatively over hundreds of square kilometres, these alterations have a much larger and significant hydrological effect. Spatial land use planning could influence such cross-scalar ecohydrological effects and feedbacks. Although residential development due to population growth is a key variable in the ecohydrological system, significantly more water is utilized in regional agricultural activities. Water withdrawals and evapotranspiration losses through irrigated agriculture represent a particularly potent leverage point in the SES.

\section{Landscape connectivity: anthropogenic infrastructure and ecological flows}

The term 'landscape connectivity' is applied in a variety of ways in the conservation biology, land-use planning and landscape ecology literatures. Taylor et al. [41] originally defined landscape connectivity as the degree to 


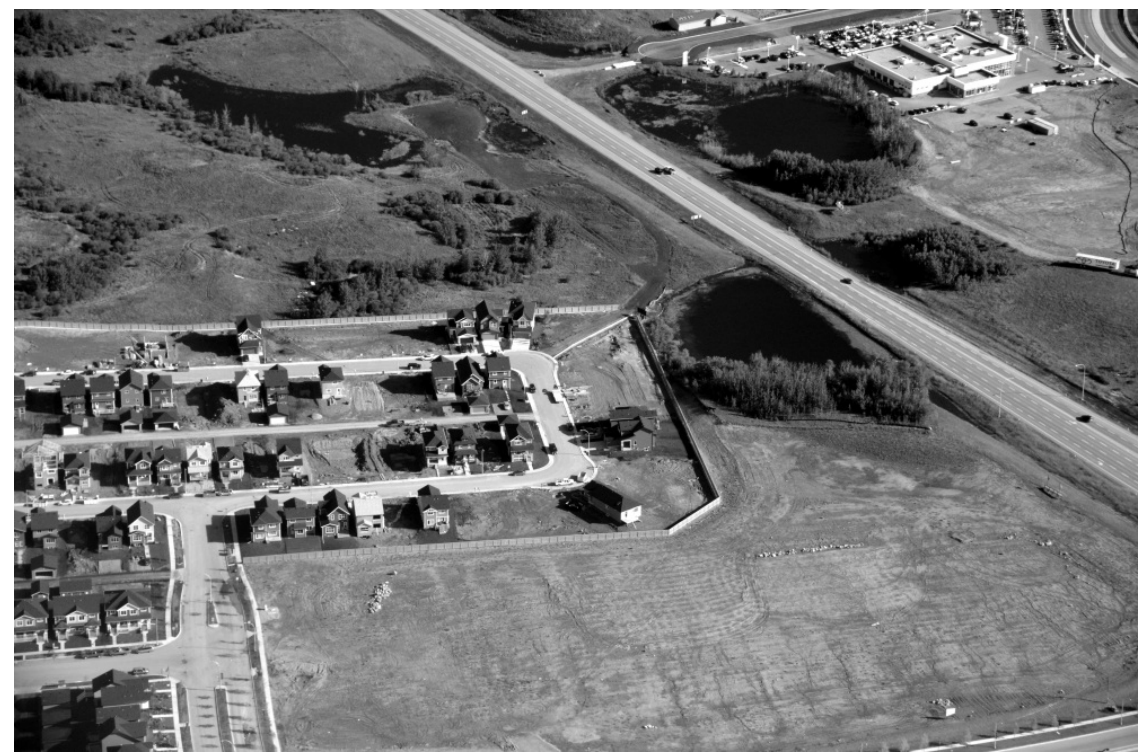

Figure 4: Photograph from the Calgary region showing a new subdivision development, a secondary highway and the alteration to existing wetland hydrology.

which the landscape facilitates (or impedes) the movement of populations, species and genes among resource patches. This definition incorporates both the physical dimensions and patterns of the landscape (structural connectivity) as well as the behavioural responses of organisms to that structure (functional connectivity). Thus, landscape connectivity is an 'emergent property' of specieslandscape interactions. Taylor et al. [42] posit that landscape connectivity is "a dynamic property that is assessed at the scale of landscape (with particular organisms or suites of organisms in mind) and is not simply an aggregate property of a set of patches within the landscape." This species focus has engendered a proliferation of highly valuable applied research focused on modeling and measuring the ability of species (or groups of species) to utilize landscapes (Hilty et al. [43]). This is useful to understanding the effects of landuse change and fragmentation on biodiversity. However, for the purpose of understanding social-ecological system couplings, we have adopted a slightly different meaning for connectivity which Biggs et al. [44] have described as "the manner by which and extent to which resources, species, or social actors disperse, migrate, or interact across ecological and social 'landscapes'." This expanded definition includes, but goes beyond an individual species focus to include ecological flows and processes as well as social processes. Defined in this way, connectivity is one of seven key principles for maintaining the capacity of social-ecological system to sustain the production of desired ecological goods and services [44].

We use connectivity as a tool to illustrate the essential nexus of social and ecological systems processes with the Calgary region. These flows of 
organisms, water, and nutrients are critical to the persistence of the natural systems that support the region (including ecological goods and services). Landscape connectivity intersects with an anthropogenic network of human activities and related infrastructure that supports the movement of people, materials, energy and information. The spatial intersection of these two systems creates a network of nodes and hubs and generates a series of natural and anthropogenic feedbacks. The long term efficiency and persistence of both systems is predicated on understanding and working with the critical points of interface or coupling and their associated feedback loops at the regional scale.

We employ a method to explore the structural and functional connectivity of the Calgary regional landscape based on the intersection of anthropogenic infrastructure or human 'footprint' with the natural landscape features in a GIS environment. The study area used is the Calgary Regional Partnership's 2007 boundary plus a $10 \mathrm{~km}$ buffer. The buffer zone was added to produce a rectangular shape in order to avoid edge effects in calculations. We used percolation theory and least-cost distance methods for network analysis (Theobald et al. [45], Landguth et al. [46], Beyhan [47]). Procedural steps included: 1$)$ a human footprint layer $(H$; all anthropogenic features mapped at a resolution of $2 \mathrm{~m}$ ) was processed to be used as a base-map; 2) conductance in the study area was estimated by using the reciprocal mean of $H$ locations (a measure landscape naturalness) with a transition matrix that represented the traversing cost to go from one location to an adjacent one; 3) landscape permeability was estimated as the mean of a series of iterations representing the accumulated traverse adjacency cost of each location; 4) energy routes representing the flow through a least-cost path were derived from the permeability layer using the landscape permeability as a surrogate for an elevation model; and, 5) configuration of the landscape permeability was analyzed using network analysis over a least cost network obtained by using a factorial approach. A detailed description of the methods we are using is presented in Quinn et al. [48].

Mapped results from these analyses are summarized in Figs 5 and 6 . The road network depicted in Fig. 5 is provided as a surrogate for human footprint as it is the dominant anthropogenic feature in the landscape. The city of Calgary is clearly visible in the centre of the figure and the predominantly square grid of the agricultural road network can be seen in the eastern 2/3 of the study area. Fig. 6 provides an overall illustration of the natural connectivity network. It is worth noting that the dendritic pattern occurring in the prairie landscape differs significantly from the more linear routes running perpendicular to the mountains and foothills to the west. Finer scale analysis will yield critical spatial points for management intervention reflecting natural and anthropogenic connectivity. To date, regional connectivity has focused on the river corridors and associated riparian zones that run west to east in the Calgary metropolitan landscape. However, application of our connectivity approach clearly demonstrates the importance of non-river north-south connectivity patterns on the west side of the study area. For example, the patterns generated in Fig. 5 provide can provide initial input into regional spatial planning by illustrating critical local leverage points for regional intervention. We are also in the process of combining 


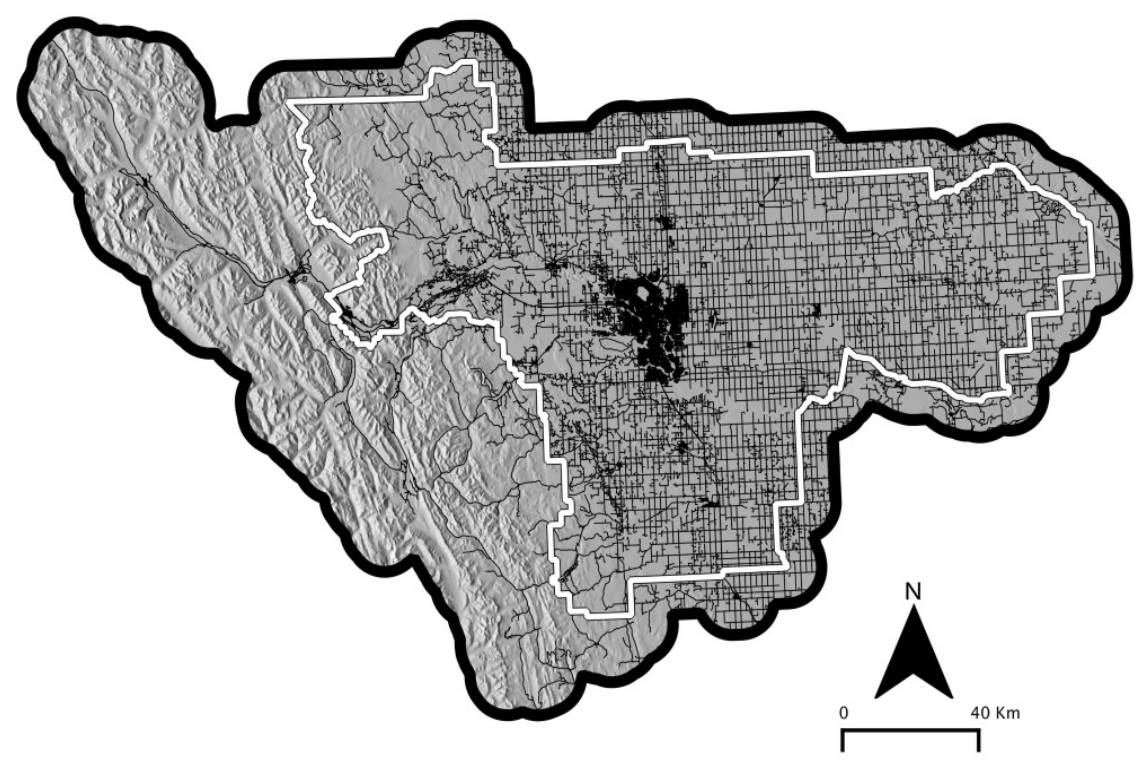

Figure 5: The road network within the Calgary regional partnership boundary (white line) and the greater study area (outside black boundary).

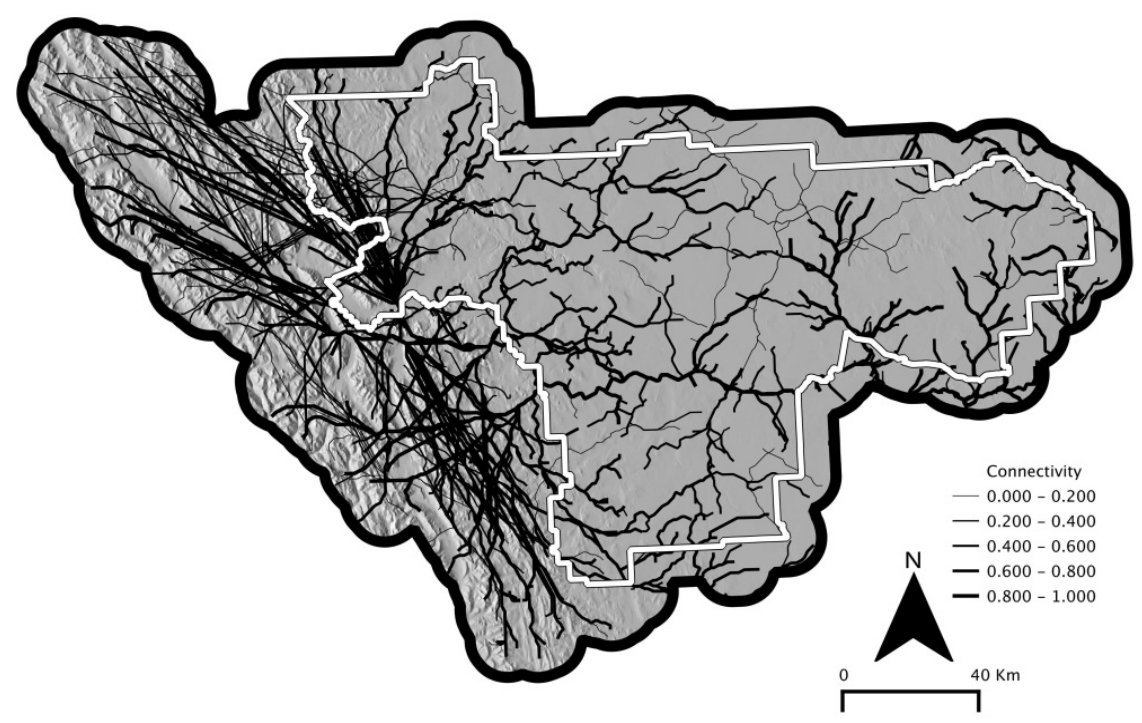

Figure 6: Connectivity within the Calgary regional partnership boundary (white line) and the greater study area (outside black boundary). 
regional socio-ecohydrology with landscape connectivity analyses. We anticipate being able to identify potentially critical SES feedbacks based on ecohydrological connectivity (Miller et al. [49]).

\section{Conclusions}

Traditional land use planning has been used as a control mechanism for ensuring certainty by "attempting to exclude instability and non-linearity as much as possible” (Timmermans et al. [50]). However, spatial planning offers significant potential for integrating natural and human system interactions and dealing with scale and subsystems. A number of sources, including Portugali [51] and Manson and O’Sulllivan [52], have dealt with uncertainty and complexity in terms of spatial planning. However, spatial planning in this context is neither technical nor communicative. Rather, it emerges as "mitigation" or "adaptive" planning which has also been referred to as 'swarm' planning. This concept of spatial planning represents an adaptive response to uncertainty that uses warning signs to anticipate uncertainty (Timmermans et al. [50]). A specific example of this approach is the "floodable landscape" of the Eemsdelta region in The Netherlands (Roggema [53]). Similarly, Rogemma et al. [54] suggest that network theory holds the key to identifying spatial location. In the context of our work in the Calgary region SES, we believe connectivity analysis provides a set of network metrics for adaptive spatial planning that can inform the identification and management of water and transportation couplings.

Scheffer et al. [11] have suggested four general warning signals for major system transitions. The fourth signal is "types of spatial patterns" and specifically includes "scale-invariant distributions of patch sizes and increased spatial coherence.” In addition to warning signals, Roggema et al. [54] suggest identifying "starting points" for system change based on network theory: "some nodes in networks are more suited to the ignition of change than others." Some key network characteristics of these starting points include (Newman et al. [55]): "enough edges, high level of clustering, fitness of nodes (based on increased connectivity) and node connections”. Research into identifying network points with the greatest potential for change has used two primary methods for network analysis (Roggema et al. [54]): “(1) the density of individual networks such as water-energy-or transport network, and (2) the number of different network types colliding at one physical location." In other words, networks with the most node density and the most connected networks are the most likely starting points for change. Based on our work to date, we believe that our landscape connectivity analysis has demonstrated spatial patterns of increased spatial coherence and edge effects within the Calgary SES. We also suggest the interface of human water use and regional ecohydrology is a critical system coupling. Together with our current in-progress SES network analysis, we believe this will enable spatial identification of clustering, fitness of nodes and node connections at a regional scale for water and transport couplings that will lead to an increased ability to undertake adaptive spatial planning in a regional governance context. 


\section{Acknowledgements}

This work was supported through grants to the authors from the Canadian Social Science and Humanities Research Council, the Calgary Regional Partnership, the Samuel Hanen Foundation and an anonymous private foundation. We are grateful for the substantive spatial modelling and analysis contributions of Dr Pablo Poujol Pina and GIS support from Greg Chernoff.

\section{References}

[1] Lui, J., Dietz, T., Carpenter, S.R., Alberti, M., Folke, C., Moran, E., Pell, A. N., Deadman, P., Kratz, T., Lubchenco, J., Ostrom, E., Ouyang, Z., Provencher, W., Redman, C.L., Schneider, S.H., and Taylor, W.W. Complexity of coupled human and natural systems. Science 317, pp. 15131516, 2007.

[2] EEA (European Environment Agency), Information for Improving Europe's Environment, EEA: Copenhagen, 1999.

[3] Berkes, F. and Folke, C. (eds), Linking Social and Ecological Systems, Cambridge University Press: Cambridge and New York, 2000.

[4] Berkes, F., Colding, J. and Folke, C. (eds), Navigating Social Ecological Systems, Cambridge University Press: Cambridge and New York, 2003.

[5] Lambin, E. F. and Meyfroidt. P., Land use transitions: Socio-ecological feedback versus socio-economic change. Land Use Policy 27, pp. 108-118, 2010.

[6] Crutzen, P. and Stoermer, E.F., The “Anthropocene”, IGBP Newsletter, 41, pp. 12, 2000.

[7] Steffen, W., Sanderson, A., Tyson, P.D., Jager, J., Matson, P.M., Moore, B., Oldfield, F., Richarson, K, Schnellnhuber, H.J., Turner, B.L. and Wasson, R.J., Global Change and the Earth System: a Planet under Pressure, The IGBP Book Series. Springer: Berlin, Germany, 2004.

[8] Vitousek, P.M, Mooney, H.A., Lubchenko, J. and Melillo, J.M. Human domination of the Earth's ecosystems. Science, 277 (5325), pp. 494-499, 1997.

[9] Zalasiewicz, J., Williams, M., Haywood, A. and Ellis, M., The anthropocence: a new epoch of geological time? Philosophical Transactions of the Royal Society A, 369, pp. 835-841, 2011.

[10] Elsevier. Anthropocene, http://www.journals.elsevier.com/anthropocene/

[11] Scheffer, M., Bascompte, J., Brock, W.A., Brovkin, V., Carpenter, S. R., Dakos, V., Held, H., van Nes, E. H., Rietkerk, M. and Sugihara, G., Earlywarning signals for critical transitions. Nature, 461, pp. 53-59, 2009.

[12] Stockholm Resilience Centre, www.stockholmresilience.org/

[13] Jahn, T., Becker, E., Keil, F. and Schramm, E., Understanding SocialEcological Systems: Frontier Research for Sustainable Development. Implications for European Research Policy, Institute for Social-Ecological Research (ISOE): Frankfurt/Main, Germany, 2009. 
[14] Bourgeron, P. S., Humphries, H. C., and Riboli-Sasco, L., Regional analysis of social-ecological systems. Natures Sciences Sociétés, 17, 185193, 2009.

[15] Walker, B., Carpenter, S., Anderies, J., Abel, N., Cummings, G., Janssen, M., Lebel, L., Norberg, J., Peterson, G. D. and Pritchard, R., Resilience management in social-ecological systems: a working hypothesis for a participatory approach. Ecology and Society, 6(1), pp. 14, [online] URL: http://www.consecol.org/vol6/iss1/art14/, 2002.

[16] Gunderson, L., and Holling, C. S., (eds). Panarchy: understanding transformations in human and natural systems, Island Press: Washington, D. C., USA, 2002.

[17] Peters, D. P. C., Sala, O. E., Allen, C. D., Covich, A. and Brunson, M., Cascading events in linked ecological and socioeconomic systems. Frontiers in Ecology and the Environment, 5(4), pp. 221-224, 2007.

[18] Milly, P.C.D., Betancourt, J., Falkenmark, M. Hirsch, R.M., Kundzewicz, Z.W., Lettenmaier, D.P., et al., Stationarity is dead: whither water management?, Science, 319, pp. 573-574, 2008.

[19] Holling, C. S. and Meffe, G. K., Command and control and the pathology of natural resource management. Conservation Biology, 10(2), pp. 328337, 1996.

[20] Walker, B. H., Gunderson, L. H., Kinzig, A. P., Folke, C., Carpenter, S. R. and Shultz, L., A handful of heuristics and some propositions for understanding resilience in social ecological systems. Ecology and Society, 11(1): pp. 13, [online] URL: http://www.ecologyandsociety.org/vol11/iss1 /art13/, 2006.

[21] Janssen, M.A., Bodin, O., Anderies, J.M., Elmqvist, T., Ernston, H., McAllister, R.R. J. et al., Toward a network perspective of the study of resilience in social-ecological systems. Ecology and Society, 11, p. 15, http://www.ecologyandsociety.org/vol11/iss1/art15/, 2006.

[22] Anderies, J. M., Janssen, M. A. and Ostrom, EA framework to analyze the robustness of social-ecological systems from an institutional perspective. Ecology and Society, 9(1):18. [online] URL: http://www.ecologyandsociety. org/vol9/iss1/art18/, 2004.

[23] Cumming, G. S., Bodin, Ö., Ernstson, H. and Elmqvist, T., Network analysis in conservation biogeography: challenges and opportunities. Diversity and Distributions, 16, pp. 414-425, 2010.

[24] Bodini, A., Building a systemic environmental monitoring and indicators for sustainability: What has the ecological network approach to offer? Ecological Indicators, 15, pp. 140-148, 2012.

[25] Stein, C., Barron, J. and Ernstson, H., A social network approach to analyze multi-stakeholders governance arrangement in water resources management: Three case studies from catchments in Burkina Faso, Tanzania and Zambia. Proceedings of the XIVth World Water Congress, 25-29 September, at Porto de Galinhas, Pernambuco, Brazil, 2011.

[26] Anderies, J. M., Walker, B. H. and. Kinzig, A.P., Fifteen weddings and a funeral: Case studies and resilience-based management. Ecology and 
Society, 11(1), p. 21, [online] URL: http://www.ecologyandsociety.org /vol11/iss1/art21/, 2006.

[27] Bodin, Ö., Crona, B. and Ernstson, H., Social networks in natural resource management: What is there to learn from a structural perspective? Ecology and Society, 11(2), [online] URL: http://www.ecologyandsociety.org/vol11 /iss2/resp2, (2006).

[28] AtKisson, A., The Sustainability Transformation: How to Accelerate Positive Change in Challenging Times, Earthscan: London, 2011.

[29] Turner, R.J.W., Franklin, R.G., Grasby, S.E., and Nowlan, G.S., Bow River Basin Waterscape, Geological Survey of Canada: Ottawa, Miscellaneous Report 90, 2005.

[30] Alberta Water Smart, South Saskatchewan River Basin Adaptation to Climate Variability Project: Initial Assessment of the Current State of the Foundational Blocks to Support Adaptation in the SSRB, Alberta Water Smart, Climate Change Emissions Management Corporation and Alberta Innovates: Edmonton, 2012.

[31] Alberta Environment, Approved Water Management Plan for the South Saskatchewan River Basin (Alberta), Alberta Environment: Calgary, 2006.

[32] Cook, B. R. and Spray, C.J., Ecosystem services and integrated water resource management: Different paths to the same end? Journal of Environmental Management, 109, pp. 93-100, 2012.

[33] C. R. Schwalm, C. A. Williams, K. Schaefer, D. Baldocchi, T. A. Black, A. H. Goldstein, et al., "Reduction in carbon uptake during turn of the century drought in western North America,” Nature Geoscience, 5, pp. 551-556, 2012.

[34] Bow River Project Research Consortium, Bow River Project: Final Report, Alberta Water Research Institute: Calgary, 2010.

[35] Bow River Basin Council, Bow River Basin: State of the Watershed Summary 2010, Bow River Basin Council: Calgary, 2010.

[36] Calgary Regional Partnership, Calgary Metropolitan Plan, Calgary Regional Partnership: Calgary, 2012.

[37] Alberta Environment, South Saskatchewan Regional Plan: Water Quantity and Quality Modelling Results, Edmonton: Government of Alberta, Alberta Environment, 2010.

[38] Chen, M., Ohman, K., Metcalfe, C., Ikonomou, M.G., Amatya, P.L. and Wilson, J., Pharmaceuticals and endocrine disruptors in wastewater treatment effluents and in the water supply system of Calgary, Alberta, Canada. Water Quality Research Journal of Canada, 41, pp. 35-364, 2006.

[39] Wilcox, B.P., Seyfried, M.S., Breshears, D.D. and McDonnell, J.J., Ecohydrologic connections and complexities in drylands: new perspectives for understanding transformative landscape change. Ecohydrology, 5, pp. 143-144, 2012.

[40] Falkenmark, M. and Rockstrom, J., The new blue and green water paradigm: Breaking new ground for water resources planning and management. Journal of Water Resource Planning and Management, 132, pp. 129-132, 2006. 
[41] Taylor, P.D., Fahrig, L., Henein, K. and Merriam, G., Connectivity is a vital element of landscape structure. Oikos, 68, pp. 571-572, 1993.

[42] Taylor, P.D., Fahrig, L. and With, K.A., Landscape connectivity: a return to basics (Chapter 2). Connectivity Conservation, ed. K.R. Crooks and M. Sanjayan, Cambridge University Press: New York, pp. 29-43, 2006.

[43] Hilty, J.A., Lidicker, W.Z. Jr. and Merenlender, A.M. Corridor Ecology: The Science and Practice of Linking Landscapes for Biodiversity Conservation, Island Press: Washington, 2006.

[44] Biggs, R., Schlüter, M., Biggs, D., Bohensky, E.L., BurnSilver, S., Cundill, G., et al., Toward principles for enhancing the resilience of ecosystem services. Annual Review of Environment and Resources, 37, pp. 421-448, 2012.

[45] Theobald, D.M., Reed, S.E., Fields, K. and Soulé, M., Connecting natural landscapes using a landscape permeability model to prioritize conservation activities in the United States. Conservation Letters, 5, pp. 123-133, 2012.

[46] Landguth, E. L., Hand, B.K., Glassy, J., Cushman, S.A. and Sawaya, M.A., UNICOR: a species connectivity and corridor network simulator. Ecography, 35(1), pp. 9-14, 2012.

[47] Beyhan, B. Developing Graph Theoretic Analysis Tools in FOSS4GIS: An Experiment in OpenJUMP with a Specific Focus on Space Syntax. FOSS4G-CEE and Geoinformatics: Prague, 2012.

[48] Quinn, M.S., Pina Poujol, P. Tyler, M.E. and Chernoff, G. Modeling the ecology of a rapidly urbanizing regional landscape: Connectivity assessment of natural integrity for ecological flows. In prep.

[49] Miller,G. R., Cable, J.M., McDonald, A.K., Bond, B., Franz, T.E., Wang, L., et al., Understanding ecohydrological connectivity in savannas: a system dynamics modelling approach. Ecohydrology, 5(2), pp. 200-220, 2012.

[50] Timmermans, W., Lopez, F. O., Roggema, R., Complexity Theory, Spatial Planning, and Adaptation to Climate Chang (Chapter 3). Swarming Landscapes, the Art of Designing for Climate Adaptation, ed. R. Roggema, Springer: Dordrecht, pp. 43-66, 2012.

[51] Portugali, J., Complexity theory as a link between space and place. Environmental Planning A, 38, pp. 647-664, 2006.

[52] Manson, S., O’Sullivan, D., Complexity theory in the study of space and place. Environmental Planning A, 38: pp. 677-692, 2006.

[53] Roggema, R., Swarming landscape (Chapter 8). Swarming Landscapes, the Art of Designing for Climate Adaptation, ed. R. Roggema, Springer: Dordrecht, pp. 167-193, 2012.

[54] Roggema, R. Vermeend, T., Timmermans, W., Transition and Transformation (Chapter 4). Swarming Landscapes, the Art of Designing for Climate Adaptation, ed. R. Roggema, Springer: Dordrecht, pp. 67-90, 012.

[55] Newman, M., Barabasi, A-L., Watts, D.J., (eds). The structure and dynamics of networks. Princeton University Press, Princeton/Woodstock, USA, 2006. 